Original Research Paper

\title{
Ethnobotany Study of Medicinal Plants by the Mbojo Tribe Community in Ndano Village at the Madapangga Nature Park, Bima, West Nusa Tenggara
}

\author{
Novi Ani ${ }^{1}$, Kurniasih Sukenti ${ }^{1}$, Evy Aryanti $^{1}$, Immy Suci Rohyani $^{2 *}$ \\ ${ }^{1}$ Program Studi Biologi, Fakultas Matematika dan Ilmu Pengetahuan Alam, Universitas Mataram, Mataram, Indonesia \\ ${ }^{2}$ Program Studi Ilmu Lingkungan, Fakultas Matematika dan Ilmu Pengetahuan Alam, Universitas Mataram, Mataram, \\ Indonesia
}

\author{
Article History \\ Received : May $19^{\text {th }}, 2021$ \\ Revised : May $28^{\text {th }}, 2021$ \\ Accepted : June 10 ${ }^{\text {th }}, 2021$ \\ Published : June $22^{\text {th }}, 2021$ \\ *Corresponding Author: \\ Immy Suci Rohyani, \\ Program Studi Ilmu \\ Lingkungan, Fakultas \\ Matematika dan Ilmu \\ Pengetahuan Alam, Universitas \\ Mataram, Mataram, Indonesia; \\ Email: immysuci@yahoo.co.id
}

\begin{abstract}
One of the cultural characteristics of people in developing countries is that traditional elements are still dominant in everyday life. These activities include the use of plants as medicinal ingredients by various ethnic groups or groups of people living in rural areas, one of which is the Mbojo Tribe, Ndano Village in Madapangga, Bima Regency, NTB. This study aims to identify the types of medicinal plants and to describe the local wisdom of the Mbojo Tribe in Ndano Village regarding the use of medicinal plants around the Madapangga Nature Tourism Park (TWA). The results of this study are expected to contribute to the development of medicinal plant research based on local wisdom for the sustainable management of TWA Madapangga. This research is descriptive exploratory. Data collection techniques in the field by means of observation, interviews and documentation. Selection of informants for interviews using purposive sampling and snowball sampling methods. Qualitative and quantitative data were analyzed descriptively related to the aspects that have been determined. The results obtained 26 species of medicinal plants that are best known and often used by the Mbojo Tribe, Ndano Village. Utilization of this medicinal plant is used to cure diseases which amount to 31 types of diseases. Based on the habitus group, the tree level is the most widely used as medicine. Meanwhile, the part (organ) of the plant that is most widely used is the leaf. The people of Ndano Village still use a simple way of concocting medicinal plants, namely by mashing (mashed, grated, kneaded) and boiled. The use of drugs, generally done by drinking, smeared and dripped. The results of this study are very useful for the development of medicinal plant research based on local wisdom for the sustainable management of TWA Madapangga.
\end{abstract}

Keywords: Medicinal Plants; Mbojo Tribe; Ndano Village.

\section{Pendahuluan}

Salah satu ciri budaya masyarakat di negara berkembang adalah masih dominannya unsur-unsur tradisional dalam kehidupan sehari-hari. Salah satu aktivitas tersebut adalah penggunaan tumbuhan sebagai bahan obat oleh berbagai suku bangsa atau sekelompok masyarakat yang tinggal di pedalaman. Tradisi pengobatan suatu masyarakat tidak terlepas dari kaitan budaya setempat (Rahayu et al, 2014). Pengobatan tradisional memiliki potensi manfaat yang sangat besar dalam pembangunan kesehatan masyarakat. Pemanfaatan bahan alam untuk pengobatan cenderung meningkat. Persentase penduduk Indonesia yang menggunakan obat tradisonal dalam pengobatan sendiri terus meningkat dalam kurun waktu tujuh tahun (2000-2006) dari 15.2\% menjadi 38.30\% (Supardi dan Susyanty, 2010) Pengobatan tradisional dengan menggunakan bahan-bahan dari tumbuhan juga lebih maju secara internasional (Kandowangko et al, 2011).

Tumbuhan obat sejak zaman dahulu memainkan peranan penting dalam menjaga kesehatan, mempertahankan stamina dan mengobati penyakit. Penggunaan tumbuhan obat sebagai bahan baku obat tradisional masih berakar kuat dalam 
kehidupan masyarakat saat ini (Pramesthi, 2008). Pemanfaatan tumbuhan obat telah dipraktekkan sejak lama oleh para leluhur yang kemudian berkembang dan menghasilkan sebuah kearifan lokal. Kearifan tersebut muncul dalam bentuk budaya pemanfaatan nilai dan khasiat dari tumbuhan obat. Di Indonesia kebiasaan mengkonsumsi obat tradisional telah lama dikembangkan dalam bentuk jamu-jamuan (Nurrani et al, 2015).

Pemanfaatan tumbuhan lokal sebagai sumber obat-obatan merupakan alternatif ke depan yang dapat dikembangkan, tumbuhan obat dapat menjadi alternatif pilihan untuk mengobati berbagai jenis penyakit, selain itu efek negatif yang ditimbulkan dari penggunaan obat tradisional lebih kecil dibandingkan penggunaan obat kimia buatan (modern) (Metananda, 2012). Salah satu kelompok masyarakat yang masih mempertahankan adat dan tradisi dalam penggunaan sumber daya alam khususnya tumbuhan sebagai obat adalah masyarakat Suku Mbojo Desa Ndano yang berada di sekitar Taman Wisata Alam Madapangga Kabupaten Bima Nusa Tenggara Barat. Pemanfaatan tumbuhan obat tersebut dilakukan hanya terbatas penyampaian dari orang tua kepada anak dan cucu secara turun temurun dalam keluarga, sehingga dikhawatirkan di tengah perkembangan arus modernisasi budaya saat ini, kearifan lokal tersebut dapat secara perlahan tergerus oleh kebiasaan yang dapat menyebabkan punahnya pengetahuan tradisional yang dimiliki masyarakat.

Kawasan TWA Madapangga menjadi salah satu sumber bahan baku tumbuhan obat, sebagian dari spesies tumbuhan obat yang terdapat di kawasan sudah dikenal umum dan dimanfaatkan oleh masyarakat setempat secara terbatas (Balai Konservasi Sumber Daya Alam NTB, 2017). Berdasarkan penelitian Ani et al (2017) terhadap 30 informan tentang pengetahuan masyarakat terkait tumbuhan obat, diperoleh sebanyak 45 spesies tumbuhan dari 27 Famili yang digunakan oleh masyarakat di Sekitar Taman Wisata Alam Madapangga untuk bahan pengobatan berbagai penyakit. Rata-rata tingkat pengetahuan masyarakat terhadap masing-masing spesies tumbuhan yaitu sebesar $81 \%$.

Tingginya persentase tingkat pengetahuan dan banyaknya spesies tumbuhan obat yang dikenali oleh masyarakat perlu ditindak lanjuti sebagai data yang berguna bagi pengembangan pemanfaatan tumbuhan obat berbasis masyarakat lokal khususnya bagi masyarakat Suku Mbojo yang berada disekitar kawasan TWA Madapangga yaitu di Desa Ndano. Tujuan penelitian ini adalah untuk mengidentifikasi jenis-jenis tumbuhan obat dan mendiskripsikan kearifan lokal masyarakat Suku Mbojo Desa Ndano terkait pemanfaatan tumbuhan obat yang berada di sekitar TWA Madapangga. Hasil penelitian ini diharapkan dapat memberi kontribusi bagi pengembangan riset tumbuhan obat berbasis kearifan lokal untuk pengelolaan TWA Madapangga yang berkelanjutan.

\section{Bahan dan Metode}

Penelitian ini bersifat deskriptif eksploratif. Lokasi penelitian yaitu di Desa Ndano Kecamatan Madapangga Kabupaten Bima, Nusa Tenggara Barat (Gambar 1).

Sampel yang digunakan dalam penelitian ini adalah semua jenis tumbuhan yang dimanfaatkan untuk pengobatan oleh masyarakat Suku Mbojo Desa Ndano di sekitar TWA Madapangga. Penentuan informan awal dalam penelitian ini dilakukan dengan metode purposive sampling dilanjutkan dengan snowball sampling. Kriteria informan yang dipilih yaitu berusia di atas 17 tahun tinggal di Desa Ndano minimal 5 tahun, mengetahui dan menggunakan tumbuhan untuk pengobatan dan bersedia dijadikan sebagai informan penelitian. Sedangkan, untuk mengetahui informasi lebih lanjut mengenai pemanfaatan tumbuhan obat, peneliti menggunakan metode snowball sampling. Metode snowball sampling merupakan metode yang penerapannya dimulai dari informan kunci (key informan) yang kemudian dapat memberikan petunjuk lebih lanjut tentang adanya informan lain yang dapat memberikan informasi yang diperlukan dalam penelitian (Metananda, 2012). 


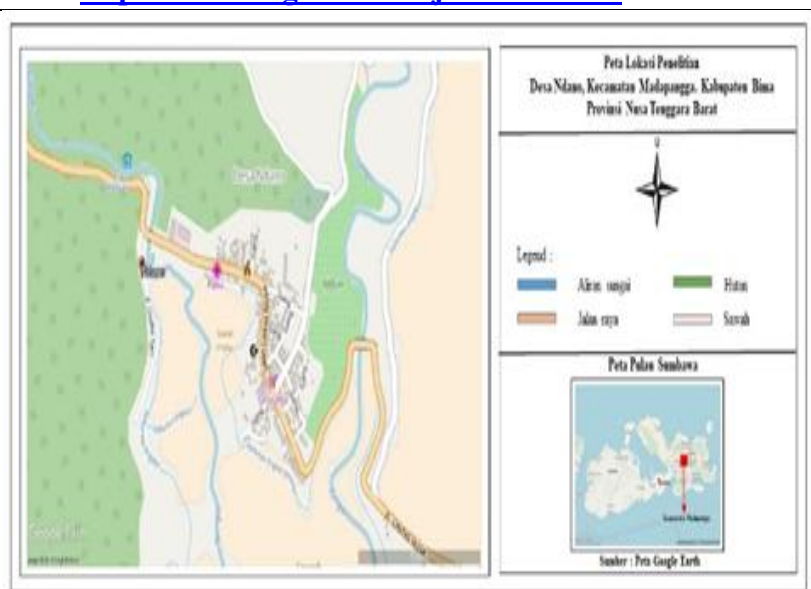

Gambar 1. Peta Lokasi Penelitian

Teknik pengumpulan data dilakukan dengan cara observasi lapangan, wawancara dan dokumentasi. Observasi dan wawancara semiterstruktur terhadap informan yang telah ditentukan berdasarkan kriteria. Wawancara dilakukan dengan menggunakan kuesioner untuk mendapatkan data mengenai jenis-jenis tumbuhan obat serta pemanfaatan tumbuhan obat yang meliputi bagian tumbuhan yang dimanfaatkan, cara meramu dan penggunaannya untuk mengobati suatu penyakit oleh masyarakat Desa Ndano di TWA Madapangga. Spesies tumbuhan obat yang ada di sekitar kawasan TWA Madapangga di dokumentasikan melalui pengambilan foto.

\section{Analisis Data}

Data dianalisis secara kualitatif dan kuantitatif. Analisis kualitatif dilakukan dengan mendeskripsikan jenis tumbuhan yang digunakan, bagian tumbuhan yang dimanfaatkan, bagaimana penggunaannya dan golongan senyawa kimia yang dikandungnya sehingga optimal dan efektif digunakan sebagai obat. Analisis kuantitatif menggunakan rumus yang digunakan dalam penelitian adalah Reported Use Value yang diperkenalkan oleh (Hoffman \& Gallaher, 2006):

$$
\mathrm{RU}=\sum_{i}^{n} \text { Spesies }_{i}
$$

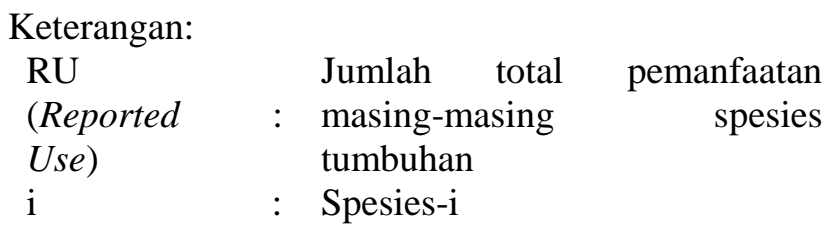

$\mathrm{n}$

: Total jenis pemanfaatan (penyakit yang disembuhkan)

Rumus ini digunakan untuk mengetahui tingkat kegunaan setiap jenis tumbuhan dalam pemanfaatannya sebagai tumbuhan obat oleh masyarakat.

\section{Hasil dan Pembahasan}

\section{Karakteristik Pendidikan dan Pengetahuan Masyarakat Suku Mbojo Desa Ndano di TWA Madapangga}

Masyarakat yang menjadi informan dalam penelitian ini sebanyak 32 orang yang terbagi ke dalam tiga kategori, yaitu yang berada pada rentang umur 17 - 25 tahun sebanyak 10 orang, pada rentang umur 25 - 40 tahun sebanyak 8 orang dan yang berada pada rentang umur lebih dari 40 tahun sebanyak 14 orang.

Hasil penelitian menunjukkan bahwa pendidikan masyarakat Desa Ndano di sekitar Taman Wisata Alam Madapangga termasuk dalam kategori rendah, yaitu sebanyak $64.29 \%$ hanya sampai tingkat Sekolah Dasar (SD). Kondisi ini diduga karena pola pikir masyarakat yang belum mementingkan pendidikan dan biaya pendidikan yang tinggi masih menjadi faktor penghambat untuk dapat melanjutkan ke jenjang yang lebih tinggi. Tingkat pendidikan ini juga berpengaruh tehadap profesi. Informan dalam penelitian ini berprofesi sebagai petani, pedagang, ibu rumah tangga (IRT) dan buruh, yang juga memiliki profesi tambahan sebagai pengobat tradisional/sando. Profesi ini juga mempengaruhi tingkat pendapatan masyarakat yang mana mempengaruhi kecenderungan masyarakat untuk memanfaatkan tumbuhan obat. Masyarakat dengan pendapatan rendah biasanya cenderung memilih pengobatan tradisional dengan menggunakan tumbuhan obat karena tidak membutuhkan biaya yang mahal (Ismail, 2015).

Masyarakat Desa Ndano menganggap tumbuhan obat sebagai tumbuhan yang dapat menyembuhkan berbagai macam penyakit, baik penyakit medis maupun penyakit non-medis yang tidak dapat disembuhkan oleh pengobatan modern. Pengetahuan tentang tumbuhan obat di Desa Ndano diwariskan secara turun-temurun atau ada juga masyarakat yang belajar pada orang lain yang lebih 
Novi Ani, et al. (2021). Jurnal Biologi Tropis, 21 (2): 456 - 469

DOI: http://dx.doi.org/10.29303/jbt.v21i2.2666

mengetahui tentang pengobatan tradisional. Masyarakat memiliki anggapan bahwa mengkonsumsi obat tradisional relatif aman, tidak memiliki dampak negatif bagi kesehatan, selain itu harganya relatif murah dan mudah didapatkan.

Keragaman jenis Tumbuahan obat yang paling sering di manfaatkan oleh masyarakat Suku Mbojo Desa Ndano di sekitar TWA Madapangga

Hasil identifkasi penelitian tumbuhan obat sebelumnya diperoleh sebanyak 27 famili yang terdiri dari 45 spesies tumbuhan yang diketahui olah masyarakat dapat digunakan sebagai obat, dari 45 spesies tersebut hanya 26 spesies yang terdiri dari 17 famili tumbuhan obat yang paling dikenal dan sering dimanfaatkan sebagai tumbuhan obat oleh masayarakat suku Mbojo (Ani et al, 2017). Hasil penelitian juga menunjukkan bahwa terdapat beberapa spesies tumbuhan tambahan untuk pengobatan tradisional yaitu 24 spesies dari 11 famili yang tidak hanya diperoleh di dalam kawasan TWA Madapangga, melainkan dapat juga ditemukan disekitar kawasan pemukiman atau telah di jadikan sebagai tanaman pekarangan, tumbuh liar disekitar area persawahan maupun perkebunan serta ada juga tanaman yang diperjual belikan di pasar tradisional. Tumbuhan tambahan ini sangat banyak dipergunakan untuk ramuan pengobatan oleh masyarakat.

Tabel 1. Jenis tumbuhan obat yang paling sering digunakan oleh masyarakat Suku Mbojo Desa Ndano di sekitar TWA Madapangga

\begin{tabular}{|c|c|c|c|c|c|c|c|}
\hline No & Famili & Nama Spesies & $\begin{array}{c}\text { Nama } \\
\text { Indonesia }\end{array}$ & $\begin{array}{l}\text { Nama } \\
\text { Lokal }\end{array}$ & Habitus & $\begin{array}{c}\text { Bagian yang } \\
\text { digunakan }\end{array}$ & $\begin{array}{l}\text { Kandungan } \\
\text { senyawa aktif }\end{array}$ \\
\hline \multirow[b]{3}{*}{1} & \multirow{3}{*}{ Annonaceae } & $\begin{array}{l}\text { Annona } \\
\text { squamosa }\end{array}$ & Srikaya & $\begin{array}{c}\text { Garoso } \\
\text { mbudi }\end{array}$ & Pohon & Daun & $\begin{array}{l}\text { Saponin, } \\
\text { flavonoid dan } \\
\text { tannin }\end{array}$ \\
\hline & & $\begin{array}{l}\text { Annona } \\
\text { muricata }\end{array}$ & Sirsak & $\begin{array}{c}\text { Garoso } \\
\text { jawa }\end{array}$ & Pohon & Daun & Acetoginin \\
\hline & & $\begin{array}{l}\text { Muntingia } \\
\text { calabura }\end{array}$ & Kersen & Anggo & Pohon & Daun, batang & $\begin{array}{l}\text { Asam askorbat, } \\
\text { serat, niasin, } \\
\text { betakaroten } \\
\text { flavanoid, tanin, } \\
\text { tritepene, saponin } \\
\text { dan polifenol }\end{array}$ \\
\hline \multirow[t]{2}{*}{2} & \multirow[t]{2}{*}{ Apocynaceae } & $\begin{array}{l}\text { Alstonia } \\
\text { spectabilis }\end{array}$ & Pulai & Rida & Pohon & $\begin{array}{c}\text { Seluruh } \\
\text { bagian } \\
\text { tumbuhan } \\
\text { (kecuali akar } \\
\text { dan bunga) }\end{array}$ & $\begin{array}{l}\text { Flavonoida, } \\
\text { saponire dan } \\
\text { polifenol }\end{array}$ \\
\hline & & $\begin{array}{l}\text { Alstonia } \\
\text { scholaris }\end{array}$ & Pulai/Bebatu & Tula & Pohon & Kulit batang & $\begin{array}{l}\text { Alkaloid ditamin, } \\
\text { echitenine, } \\
\text { echitamine dan } \\
\text { strictamine }\end{array}$ \\
\hline 3 & Arecaceae & Areca catechu & Pinang & $U^{\prime} a$ & Pohon & Buah & $\begin{array}{l}\text { Tanin dan } \\
\text { alkaloid }\end{array}$ \\
\hline 4 & Asteraceae & $\begin{array}{l}\text { Chromolaena } \\
\text { odorata }\end{array}$ & Kirinyuh & Golka & Perdu & Daun & $\begin{array}{l}\text { Seskuiterpen, } \\
\text { lakton, triterpen } \\
\text { pentasiklik, } \\
\text { alkohol, alkaloid, } \\
\text { tanin, polifenol, } \\
\text { saponin, dan } \\
\text { sterol }\end{array}$ \\
\hline 5 & Euphorbiaceae & $\begin{array}{l}\text { Jatropha } \\
\text { curcas }\end{array}$ & Jarak pagar & Tatanga & Perdu & $\begin{array}{l}\text { Daun, batang } \\
\text { (diambil } \\
\text { getah) }\end{array}$ & $\begin{array}{l}\text { Saponin, alkaloid, } \\
\text { glikosida, tanin, } \\
\text { fitosterol dan } \\
\text { flavonoid }\end{array}$ \\
\hline
\end{tabular}




\begin{tabular}{|c|c|c|c|c|c|c|c|}
\hline & & $\begin{array}{l}\text { Euphorbia } \\
\text { thymifolia }\end{array}$ & Patikan cina & $\begin{array}{c}\text { Kana'a } \\
\text { keta }\end{array}$ & Herba & $\begin{array}{c}\text { Seluruh } \\
\text { bagian } \\
\text { tumbuhan } \\
\text { (kecuali akar } \\
\text { dan bunga) } \\
\end{array}$ & $\begin{array}{l}\text { Myricil alcohol, } \\
\text { taraxerol, } \\
\text { tirucalol, hentri- } \\
\text { acontane dan } \\
\text { cosmosin }\end{array}$ \\
\hline & & $\begin{array}{l}\text { Euphorbia } \\
\text { hirta }\end{array}$ & Patikan kebo & Kana'a & Herba & Batang & $\begin{array}{l}\text { Tanin, saponin, } \\
\text { flavanoid, } \\
\text { terpenoid, } \\
\text { alkanoid dan } \\
\text { senyawa polifenol }\end{array}$ \\
\hline \multirow[t]{3}{*}{6} & \multirow[t]{3}{*}{ Fabaceae } & $\begin{array}{l}\text { Tamarindus } \\
\text { indica }\end{array}$ & Asam & Mange & Pohon & $\begin{array}{l}\text { Daun, kulit } \\
\text { akar }\end{array}$ & $\begin{array}{l}\text { Senyawa fenol, } \\
\text { glikolisida, mallic } \\
\text { acid, tartaric acid, } \\
\text { getah, pektin, } \\
\text { glukosa, calcium, } \\
\text { potassium, } \\
\text { magnesium, besi, } \\
\text { zinc dan vitamin } \\
\text { A }\end{array}$ \\
\hline & & $\begin{array}{l}\text { Leucaena } \\
\text { leucocephala }\end{array}$ & Lamtoro & Pate & Pohon & Buah & Mimosin \\
\hline & & Cassia alata & Ketapeng cina & $\begin{array}{c}\text { Kakapi } \\
\text { na'e }\end{array}$ & Perdu & Daun & $\begin{array}{l}\text { Alkaloid, saponin, } \\
\text { tannin, steroid, } \\
\text { antrakuinon, } \\
\text { flavonoid dan } \\
\text { karbohidrat }\end{array}$ \\
\hline 7 & Loganiaceace & $\begin{array}{l}\text { Strychnos } \\
\text { lucida }\end{array}$ & $\begin{array}{l}\text { Bidara laut, } \\
\text { Kayu ular }\end{array}$ & Songga & Pohon & $\begin{array}{c}\text { Seluruh } \\
\text { bagian } \\
\text { tumbuhan } \\
\text { (kecuali akar } \\
\text { dan bunga) } \\
\end{array}$ & $\begin{array}{l}\text { Alkaloid, tanin, } \\
\text { steroid dan } \\
\text { triterpenoid }\end{array}$ \\
\hline 8 & Lythraceae & $\begin{array}{l}\text { Tinospora } \\
\text { crispa }\end{array}$ & Brotowali & Tamba & Liana & Batang & $\begin{array}{l}\text { Alkaloid, } \\
\text { flavonoid, flavon } \\
\text { glikosida, } \\
\text { triperten, diterpen, } \\
\text { firoditerpen, } \\
\text { lakton, sterol, } \\
\text { lignin dan } \\
\text { nukleosida }\end{array}$ \\
\hline 9 & Meliaceae & $\begin{array}{l}\text { Swetenia } \\
\text { mahagoni }\end{array}$ & Mahoni & Mahoni & Pohon & $\begin{array}{c}\text { Buah, kulit } \\
\text { batang }\end{array}$ & $\begin{array}{l}\text { Flavanoid dan } \\
\text { saponin }\end{array}$ \\
\hline \multirow[t]{2}{*}{10} & Moringaceae & $\begin{array}{l}\text { Moringa } \\
\text { oleifera }\end{array}$ & Kelor & Perongge & Pohon & $\begin{array}{l}\text { Daun, kulit } \\
\text { batang }\end{array}$ & $\begin{array}{l}\text { Flavonoid, } \\
\text { alkaloid, steroid, } \\
\text { tanin, saponin, } \\
\text { antrakuinon, } \\
\text { terpenoid, fenol, } \\
\text { minyak atsiri } \\
\end{array}$ \\
\hline & \multirow[b]{2}{*}{ Myrtaceae } & $\begin{array}{l}\text { Eugenia } \\
\text { cumini }\end{array}$ & $\begin{array}{l}\text { Duwet/ } \\
\text { Jamblang }\end{array}$ & Duwe & Pohon & $\begin{array}{l}\text { Kulit batang, } \\
\text { daun }\end{array}$ & $\begin{array}{l}\text { Tanin dan } \\
\text { karbohidrat }\end{array}$ \\
\hline 11 & & $\begin{array}{l}\text { Psidium } \\
\text { guajava }\end{array}$ & Jambu batu & $\begin{array}{l}\text { Jambu } \\
\text { doro }\end{array}$ & Perdu & Daun, buah & $\begin{array}{l}\text { Tanin, minyak } \\
\text { atsiri, asam } \\
\text { ursolat, asam } \\
\text { psidiolat, asam } \\
\text { kratogolat, asam } \\
\text { oleanolat, asam } \\
\text { guajaverin dan } \\
\text { vitamin. }\end{array}$ \\
\hline 12 & Muntingiaceae & $\begin{array}{l}\text { Schleichera } \\
\text { oleosa }\end{array}$ & Kesambi & Sambi & Pohon & Kulit batang & Asam sianida \\
\hline
\end{tabular}




\begin{tabular}{|c|c|c|c|c|c|c|c|}
\hline 13 & Phyllanthaceae & $\begin{array}{l}\text { Sauropus } \\
\text { androgynous }\end{array}$ & Katuk & Kambesi & Perdu & Daun & $\begin{array}{l}\text { Protein, vitamin } \\
\mathrm{K}, \text { provitamin } \mathrm{A} \text {, } \\
\mathrm{B}, \mathrm{C}, \mathrm{Fe}, \text { kalium, } \\
\mathrm{Ca}, \mathrm{P}, \mathrm{Mg} \text { dan } \\
\text { papaverine, }\end{array}$ \\
\hline 14 & Piperaceae & $\begin{array}{l}\text { Piper } \\
\text { retrofractum }\end{array}$ & Cabai hutan & Sabia & Liana & Buah & $\begin{array}{l}\text { Alkaloid, } \\
\text { polifenol, minyak } \\
\text { atsiri, asam } \\
\text { palmitat, asam } \\
\text { tetrahidropiperat, } \\
\text { piperin dan } \\
\text { sesamin }\end{array}$ \\
\hline 15 & Rubiaceae & $\begin{array}{l}\text { Morinda } \\
\text { citrifolia }\end{array}$ & Mengkudu & Nonu & Pohon & Bunga, buah & Terponoid \\
\hline \multirow[t]{2}{*}{16} & \multirow[t]{2}{*}{ Rutaceae } & $\begin{array}{l}\text { Citrus } \\
\text { aurantifolia }\end{array}$ & Jeruk nipis & $\begin{array}{l}\text { Dungga } \\
\quad \text { ncia }\end{array}$ & Pohon & Buah & $\begin{array}{l}\text { Asam nitrat, asam } \\
\text { amino, minyak } \\
\text { atsiri, glikosida, } \\
\text { lemak, fosfor, } \\
\text { vitamin B1 dan C }\end{array}$ \\
\hline & & Citrus hystrix & Jeruk purut & $\begin{array}{c}\text { Dungga } \\
\text { mbudi }\end{array}$ & Pohon & Buah & $\begin{array}{l}\text { Minyak atsiri } \\
\text { citronelal, } \\
\text { citronelol,nerol } \\
\text { dan limonene } \\
\end{array}$ \\
\hline 17 & Zingiberaceae & $\begin{array}{l}\text { Curcuma } \\
\text { domestica }\end{array}$ & Kunyit & Huni & Herba & Rimpang & $\begin{array}{l}\text { kurkumin dan } \\
\text { minyak atsiri }\end{array}$ \\
\hline
\end{tabular}

Habitus tumbuhan obat di Desa Ndano digolongkan dalam beberapa tipe habitus yaitu pohon (16 spesies), perdu (5 spesies), herba (3 spesies) dan liana (2 spesies). Pohon memiliki tingkat tertinggi dalam pemanfaatan tumbuhan obat. Pohon memiliki kulit batang yang lunak dan banyak mengandung getah sehingga habitus ini banyak digunakan sebagai bahan baku obat oleh masyarakat Desa Ndano. Bagian pohon yang biasa dimanfaatkan sebagai obat sebagian besar berasal dari daun, kulit kayu, buah, biji dan akar. Pohon diduga memiliki jumlah kandungan kimiawi yang lebih banyak dibandingkan dengan tipe habitus lainnya (Herbie, 2015).

Tingkat habitus yang kedua paling banyak digunakan yaitu perdu. Habitus perdu memiliki ciriciri kecil, semak rendah, umumnya kurang dari $2 \mathrm{~m}$, habitus perdu merupakan tumbuhan obat semusim yang sering ditemukan tumbuh liar di pekarangan atau area persawahan, tumbuh sebagai gulma atau tanaman penggangu. Habitus herba juga merupakan tumbuhan obat yang cukup dikenal oleh masyarakat serta sering ditemukan dipekarangan masyarakat. Habitus herba merupakan tumbuhan yang mudah untuk dibudidayakan dan tidak memerlukan lahan yang luas. Hal ini sejalan dengan pernyataan Arizona (2011), habitus herba sangat mudah penanamannya, cepat dalam pertumbuhan, tidak memerlukan lahan luas dan cukup di pekarangan rumah.

Bagian (organ) tumbuhan yang sering dimanfaatkan oleh masyarakat sebagai tumbuhan obat diperoleh hasil yaitu daun (10 spesies), buah (7 spesies), kulit batang (3 spesies), seluruh bagian tanaman ( 3 spesies), batang ( 2 spesies) dan rimpang (1 spesies). Setiap bagian tumbuhan memiliki khasiat yang berbeda. Bagian yang paling tinggi (dominan) dimanfaatkan yaitu daun. Daun merupakan bagian (organ) tumbuhan yang banyak digunakan sebagai obat tradisional karena daun umumnya bertekstur lunak, mempunyai kandungan air yang tinggi (70-80\%), selain itu daun merupakan tempat akumulasi fotosintat yang mengandung zat organik yang memiliki sifat menyembuhkan penyakit. Zat yang banyak terdapat di daun yaitu minyak atsiri, fenol, senyawa kalium, tanin dan klorofil. Keuntungan lain dari daun yaitu memiliki serat lunak sehingga mudah untuk mengekstrak zatzat yang digunakan sebagai obat (Zaman, 2009).

Selain daun, bagian (organ) yang digunakan untuk obat adalah buah, penggunaan buah oleh masyarakat suku Mbojo desa Ndano yaitu 7 spesies. Menurut Gunawan (2007), menyatakan bahwa buah banyak mengandung unsur potensial pembersih sisasisa makanan dari usus besar, buah menghemat energi karena tidak memerlukan proses pencernaan 
panjang. Buah memasok energi lebih cepat, karena zat gulanya bisa langsung diserap oleh tubuh. Selanjutnya bagian (organ) yang digunakan yaitu batang, kulit batang dan seluruh bagian tanaman.

Bagian (organ) tumbuhan lain yang juga penting digunakan adalah rimpang. Rimpang diketahui mengandung senyawa atsiri yang terdiri dari sineol, metal sinamat, galangin, dan alpine. Kandungan-kandungan ini memiliki banyak manfaat, diantaranya melancarkan peredaran darah dan menghambat mikroba (Hariana, 2005). Menurut Kuntorini (2005), tumbuhan yang termasuk dalam famili Zingiberaceae memiliki efek farmakologis yang berkhasiat sebagai obat dan mampu memperkuat khasiat obat lain yang dicampurkannya. Tumbuhan dari famili Zingiberaceae salah satunya yaitu kunyit (Curcuma domestica), kunyit mengandung minyak atsiri yang dapat memberikan efek anti mikroba (Purba \& Martosipono, 2009).

\section{Pemanfaatan tumbuhan dan Ramuan Obat untuk beragam penyakit yang diderita Masyarakat Suku Mbojo Desa Ndano di TWA Madapanga}

Pengobatan dengan menggunakan tumbuhan yang berkhasiat obat dapat diklasifikasikan menjadi dua macam, yaitu pengobatan penyakit luar dan penyakit dalam (Tabel 2). Hasil penelitian menunjukkan bahwa masyarakat setempat dalam mengolah tumbuhan obat ini lebih banyak untuk pengobatan penyakit dalam. Tumbuhan yang dimanfaatkan untuk pengobatan penyakit dalam berjumlah 20 spesies dan sisanya digunakan untuk pengobatan penyakit luar. Penyakit luar merupakan penyakit yang menyerang bagian luar tubuh seperti kulit yang disebabkan oleh berbagai macam penyebab. Beberapa penyebab penyakit luar yaitu kebersihan diri yang buruk, virus, alergi, daya tahan tubuh rendah, terkena benda tajam atau terkena guna-guna.

Proses pembuatan obat tradisioanal, para sando (pengobat tradisioanal) terkadang melakukan beberapa ritual berupa pembacaan do'a agar tumbuhan yang dibuat tersebut berkhasiat untuk menyembuhkan sakit/penyakit. Ritual pembacaan do'a tersebut menggambarkan bahwa masyarakat lokal memiliki perilaku religius, tidak terdapat unsur magis yang berkaitan dengan cerita-cerita mitos (kepercayaan) di masyarakat.

Tabel 2. Jenis penyakit dan Pemanfaatan tumbuhan sebagai obat oleh Masyarakat suku Mbojo Desa Ndano

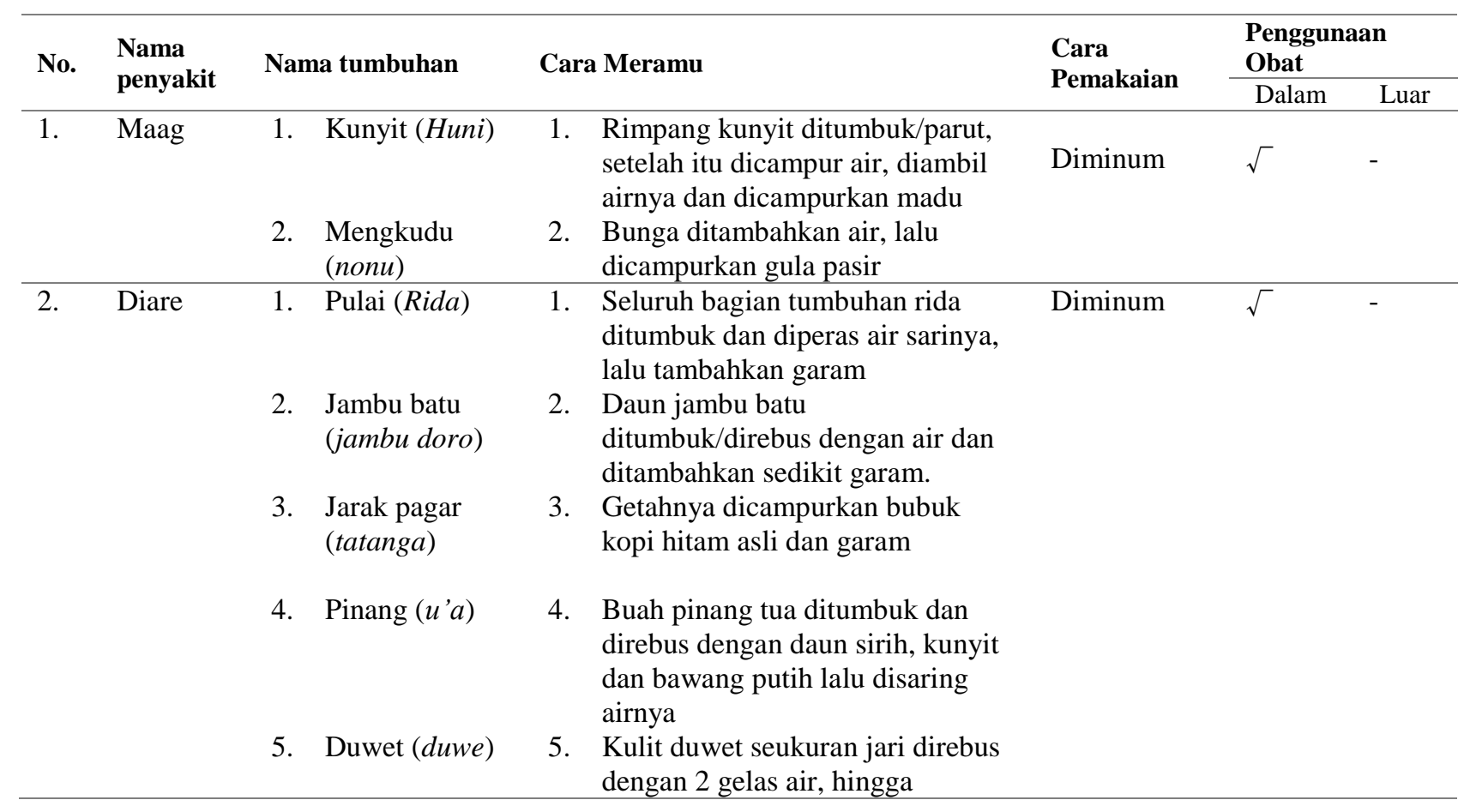


menyusut menjadi segelas air.

Setelah itu disaring

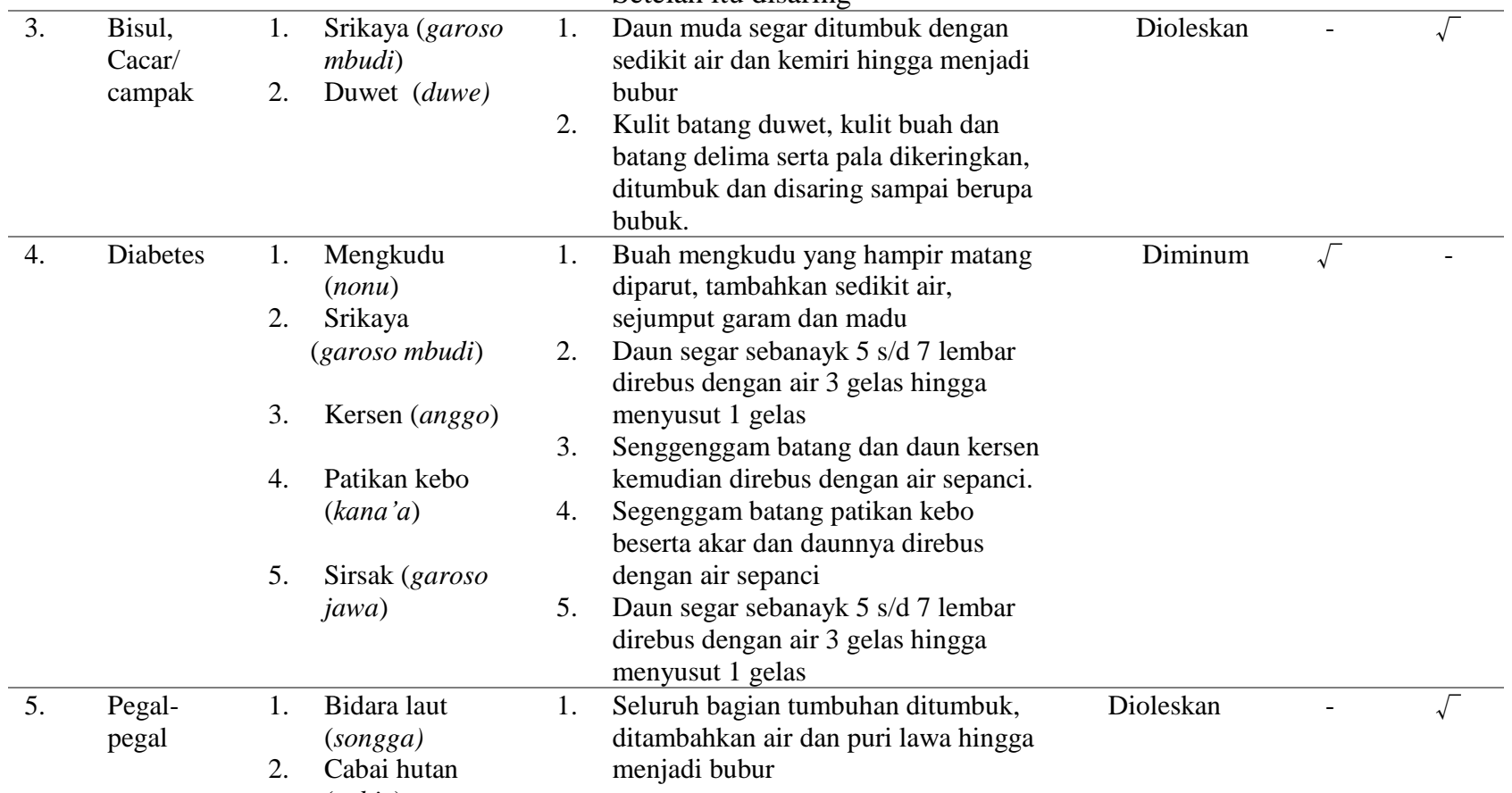

2. Buah ditumbuk dengan beras yang sudah direndam, ditambahkan kunyit

3. Jarak pagar (tatanga) dan bahan lainnya (markani), beri sedikit air

3. Daun jarak pagar, tembakau, kulit telur ayam kampung, puri lawa (Bahasa bima) dan daun kelor

4. Duwet (duwe) ditumbuk dan beri sedikit air, tumbuk hingga menjadi bubur

4. Daun jarak pagar, puri lawa, beras yang sudah direndam dan kencur ditumbuk, setelah itu diberikan sedikit air

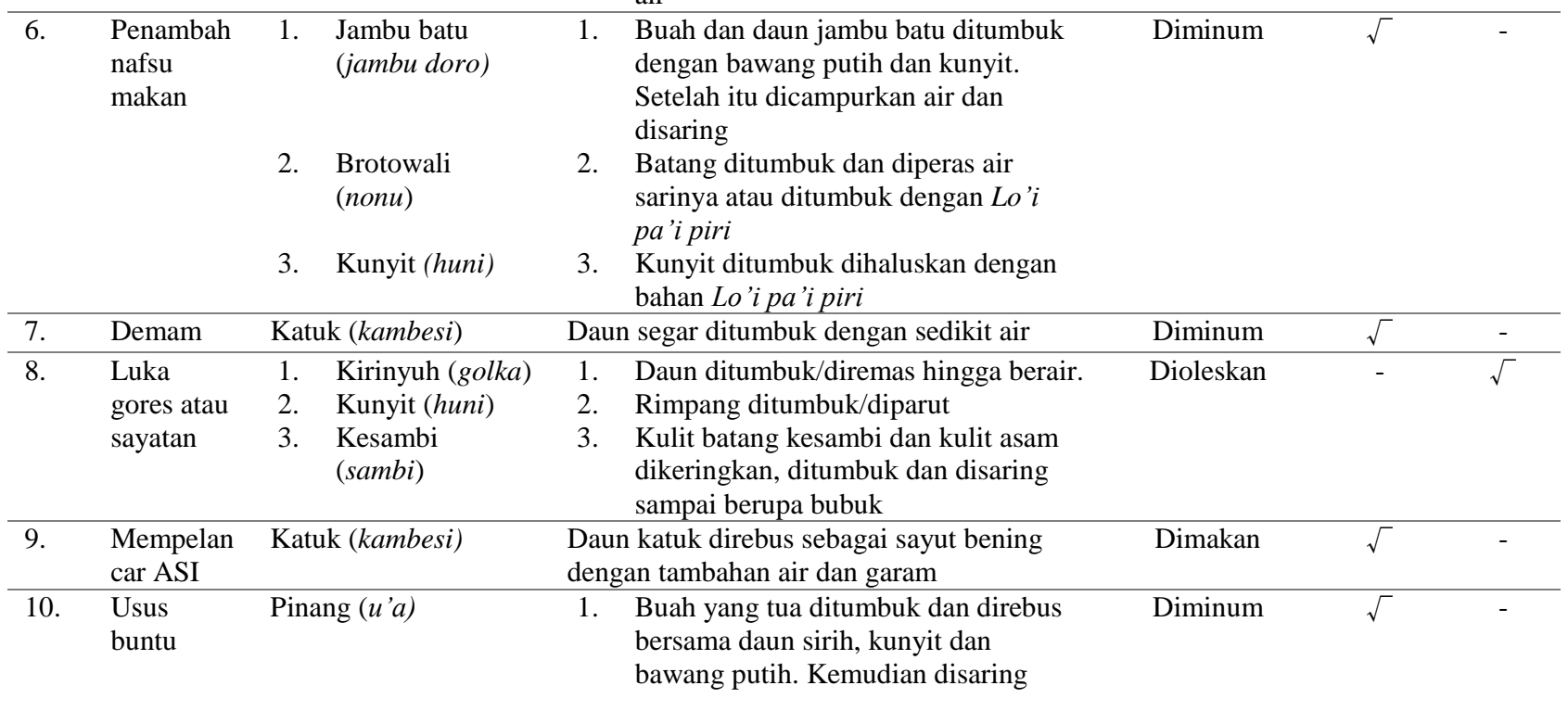


2. Seluruh bagian tumbuhan krokot ditumbuk dengan beras yang sudah direndam, tambahkan sedikit air

\begin{tabular}{lll}
\hline 11. Asam urat & 1. & $\begin{array}{l}\text { Srikaya (garoso } \\
\text { mbudi) }\end{array}$ \\
2. & $\begin{array}{l}\text { Patikan cina } \\
\text { (kana'a keta) }\end{array}$ \\
3. & $\begin{array}{l}\text { Mengkudu } \\
(\text { nonu })\end{array}$ \\
4. & Kersen (anggo)
\end{tabular}

1. Daun srikaya direbus dengan air secukupnya

Diminum

2. Seluruh bagian tumbuhan patikan cina direbus dengan air

3. Buah mengkudu yang hampir matang diparut, tambahkan sedikit air, sejumput garam dan madu

4. Senggenggam batang dan daun kersen kemudian direbus dengan air sepanci

\begin{tabular}{|c|c|c|c|c|c|c|}
\hline 12. & Sakit mata & $\begin{array}{l}\text { Pisang (kalo) dan } \\
\text { Kedondong (kendodo) }\end{array}$ & $\begin{array}{l}\text { Akar pisang \& kedondong ditumbuk, } \\
\text { setelah itu diambil air sarinya dan } \\
\text { tambahkan madu }\end{array}$ & Diteteskan & - & $\sqrt{ }$ \\
\hline 13. & $\begin{array}{l}\text { Tekanan } \\
\text { darah } \\
\text { tinggi }\end{array}$ & Mahoni (mahoni) & $\begin{array}{l}\text { Kulit batang ditumbuk dan ambil air sarinya } \\
\text { kemudian ditambah embrio kelapa, temu } \\
\text { giring, santan kelapa dan ketan hitam yang } \\
\text { telah digerus }\end{array}$ & Diminum & $\sqrt{ }$ & - \\
\hline 14. & Keseleo & Lamtoro (pate) & $\begin{array}{l}\text { Daun beberapa lembar ditumbuk bersama } \\
\text { kemiri, kunyit dan beras yang sudah } \\
\text { direndam. Tambahkan sedikit air }\end{array}$ & Dioleskan & & $\sqrt{ }$ \\
\hline 15. & Cacingan & Lamtoro (pate) & Biji muda & $\begin{array}{c}\text { Diminum/ } \\
\text { dimakan }\end{array}$ & $\sqrt{ }$ & - \\
\hline 16. & $\begin{array}{l}\text { Wasir dan } \\
\text { disentri }\end{array}$ & $\begin{array}{l}\text { Patikan cina (kana'a } \\
\text { keta) }\end{array}$ & $\begin{array}{l}\text { Segenggam batang, akar, daun direbus } \\
\text { dengan } 3 \text { gelas air, lalu tambahkan } 1-2 \\
\text { sendok gula pasir. Direbus sampai mendidih } \\
\text { dan tersisa } 1 \text { gelas }\end{array}$ & Diminum & $\sqrt{ }$ & - \\
\hline \multirow[t]{2}{*}{17.} & $\begin{array}{l}\text { Terkena } \\
\text { guna-guna }\end{array}$ & $\begin{array}{l}\text { 1. Jarak pagar } \\
\text { (tatanga) }\end{array}$ & $\begin{array}{l}\text { 1. Daun jarak pagar, tembakau, kulit } \\
\text { telur ayam kampung, puri lawa } \\
\text { (Bahasa bima) dan daun kelor } \\
\text { ditumbuk dan beri sedikit air. Tumbuk } \\
\text { hingga menjadi bubur }\end{array}$ & Dioleskan & - & $\sqrt{ }$ \\
\hline & & $\begin{array}{l}\text { 2. Srikaya (garoso } \\
\text { mbudi) }\end{array}$ & $\begin{array}{l}\text { 2. Daun berjumlah ganjil, diremas dan } \\
\text { dioleskan/dibalurkan ke penderita }\end{array}$ & & & \\
\hline 18. & Ketombe & $\begin{array}{l}\text { Jeruk purut (dungga } \\
\text { mbudi) }\end{array}$ & $\begin{array}{l}\text { Buah jeruk purut diparut, lalu tambahkan } \\
\text { santan }\end{array}$ & Dioleskan & - & $\sqrt{ }$ \\
\hline 19. & Panuan & $\begin{array}{l}\text { Ketapeng cina (kakapi } \\
\text { na'e) }\end{array}$ & Daun ditumbuk & Dioleskan & - & $\sqrt{ }$ \\
\hline 20. & Jerawatan & Asam (mangge) & $\begin{array}{l}\text { Daun asam ditumbuk bersama beras yang } \\
\text { sudah direndam }\end{array}$ & Dioleskan & & $\sqrt{ }$ \\
\hline 21. & Batuk & $\begin{array}{l}\text { Jeruk nipis (dungga } \\
\text { ncia) }\end{array}$ & Buah diperas dan ditambahkan kecap manis & Diminum & $\sqrt{ }$ & - \\
\hline 22. & $\begin{array}{l}\text { Muntah } \\
\text { darah }\end{array}$ & Asam (mangge) & $\begin{array}{l}\text { Kulit akar, kulit mahoni, asam ditumbuk } \\
\text { dengan air dan ditambahkan gula pasir }\end{array}$ & Diminum & $\sqrt{ }$ & - \\
\hline 23. & Sakit gigi & $\begin{array}{l}\text { Pulai (Rida) dan } \\
\text { Bebatu (Tula) }\end{array}$ & Batang dipetik dan menghasilkan getah & Diteteskan & - & $\sqrt{ }$ \\
\hline \multirow[t]{2}{*}{24.} & $\begin{array}{l}\text { Kencing } \\
\text { batu }\end{array}$ & $\begin{array}{l}\text { J. Jarak pagar } \\
\text { (tatanga })\end{array}$ & $\begin{array}{l}\text { 1. Daun ditumbuk dan dicampurkan } \\
\text { dengan minuman sprite }\end{array}$ & Diminum & $\sqrt{ }$ & - \\
\hline & & $\begin{array}{l}\text { 2. Patikan kebo } \\
(\text { kana'a })\end{array}$ & $\begin{array}{l}\text { 2. Segenggam batang patikan kebo } \\
\text { beserta akar dan daunnya direbus } \\
\text { dengan air sepanci }\end{array}$ & & & \\
\hline 25. & $\begin{array}{l}\text { Anak } \\
\text { sehat }\end{array}$ & Pinang $\left(u^{\prime} a\right)$ & $\begin{array}{l}\text { Buah, jahe, cengkeh, pala dan bawang putih } \\
\text { ditumbuk dan ditambahkan air. Kemudian } \\
\text { disaring, diambil airnya }\end{array}$ & Diminum & $\sqrt{ }$ & - \\
\hline 26. & $\begin{array}{l}\text { Penyakit } \\
\text { kuning }\end{array}$ & Mengkudu (nonu) & $\begin{array}{l}\text { Buah mengkudu yang hampir matang } \\
\text { diparut, tambahkan sedikit air, sejumput } \\
\text { garam dan madu }\end{array}$ & Diminum & $\sqrt{ }$ & - \\
\hline
\end{tabular}


Novi Ani, et al. (2021). Jurnal Biologi Tropis, 21 (2): 456 - 469

DOI: http://dx.doi.org/10.29303/jbt.v21i2.2666

\begin{tabular}{|c|c|c|c|c|c|c|}
\hline 27. & $\begin{array}{l}\text { Ibu-ibu } \\
\text { selesai } \\
\text { melahirka } \\
\mathrm{n}\end{array}$ & Pulai/bebatu (Tula) & $\begin{array}{l}\text { Kulit batang dikeringkan, ditumbuk dan } \\
\text { dicampurkan dengan ramuan obat Lo'i } p a^{\prime} i \\
\text { piri }\end{array}$ & Diminum & $\sqrt{ }$ & - \\
\hline 28. & Malaria & $\begin{array}{l}\text { Mahoni (mahoni) dan } \\
\text { Bidara laut (songga) }\end{array}$ & Biji & Diminum & $\sqrt{ }$ & - \\
\hline 29. & Gigi kuat & Pinang $\left(u^{\prime} a\right)$ & Buah, kapur dan daun sirih dikunyah. & Dikunyah & $\sqrt{ }$ & - \\
\hline 30. & $\begin{array}{l}\text { Mempelan } \\
\text { carkan } \\
\text { peredaran } \\
\text { darah }\end{array}$ & Kunyit (huni) & $\begin{array}{l}\text { Kunyit ditumbuk dihaluskan dengan bahan } \\
\text { Lo'i pa'i piri }\end{array}$ & Diminum & $\sqrt{ }$ & - \\
\hline 31. & Kolesterol & Kunyit (huni) & $\begin{array}{l}\text { Kunyit ditumbuk dihaluskan dengan bahan } \\
\text { Lo'i pa'i piri }\end{array}$ & Diminum & $\sqrt{ }$ & - \\
\hline
\end{tabular}

Cara pemanfaatan tumbuhan obat oleh masyarakat Desa Ndano sangat bergantung dari jenis tumbuhan, manfaat tumbuhan itu sendiri dan jenis penyakit yang diderita oleh masyarakat. Masyarakat Desa Ndano masih menggunakan cara sederhana dalam meramu tumbuhan obat, yaitu dengan cara dihaluskan (ditumbuk, diparut, diremas) dan direbus. Sedangkan, cara penggunaan yaitu dengan cara diminum, dioleskan dan diteteskan.

Merebus merupakan cara pemanfaatan tumbuhan paling banyak dilakukan oleh masyarakat Desa Ndano. Merebus biasanya digunakan untuk pengobatan penyakit dalam. Perebusan dilakukan agar ramuan obat bisa bertahan sampai satu minggu. Proses perebusan bertujuan untuk mengekstrakkan atau menarik zat-zat aktif dari dalam tumbuhan obat dengan media air, karena air dikenal sebagai zat pelarut yang baik. Lama perebusan bergantung pada tekstur masing-masing tumbuhan dan jenis bahan ramuan itu sendiri, ada yang direbus hingga airnya menyusut dan ada yang hanya sekedar mendidih. Tumbuhan yang direbus sebagai obat diare yaitu daun jambu batu (Psidium guajava). Efek antidiare ditimbulkan dengan cara mengurangi pergerakan usus.
Ada juga tumbuhan obat dikonsumsi langsung tanpa diolah terlebih dahulu, biasanya digunakan untuk pengobatan penyakit dalam. Beberapa jenis tumbuhan yang digunakan adalah buah lamtoro (Leucaena leucocephala) untuk mengobati cacingan, mahoni (Swetenia mahagoni) dan bidara laut (Strychnos lucida) untuk mengobati malaria. Menurut kepercayaan masyarakat Desa Ndano, dengan meminum air rebusan biji bidara laut atau songga berkhasiat tidak memiliki penyakit selama 7 tahun.

Ramuan yang ditumbuk, diremas, atau diparut biasanya digunakan untuk pengobatan penyakit luar. Jenis tumbuhannya yaitu Jatropha curcas, Curcuma domestica, Tamarindus indica, Eugenia cumini, Leucaena leucocephala, Annona squamosa yang dipercaya masyarakat berkhasiat untuk menyembuhkan penyakit terkena guna-guna, bisul , luka bakar maupun pegal-pegal. Penyakit terkena guna-guna menggunakan daun jarak pagar, tembakau, kulit telur ayam kampung, puri lawa, dan daun kelor. Semua bahan tersebut dicampur dengan sedikit air dan ditumbuk hingga menjadi bubur. 


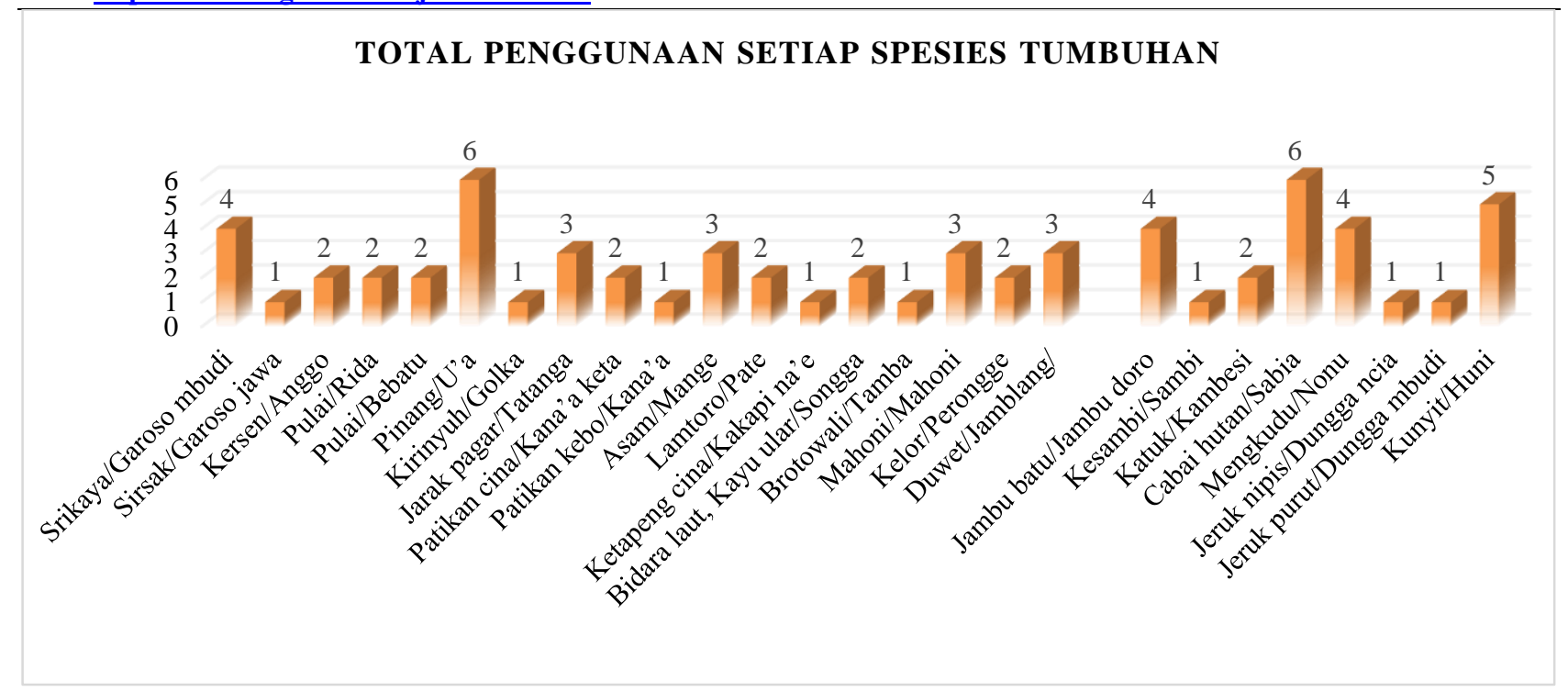

Gambar 2. Jumlah total pemanfaatan masiang-masing spesies tumbuhan (RU)

Berdasarkan jumlah total pemanfaatan masing-masing spesies tumbuhan (RU) didapatkan tingkat pemanfaatan setiap spesies tumbuhan obat oleh masyarakat. Tingkat pemanfaatan tertinggi yaitu Piper retrofractum (cabai hutan/sabia) dan Areca catechu (Pinang/u'a) untuk mengobati 6 jenis penyakit. Tingkat kedua yaitu Curcuma domestica (kunyit/huni) untuk mengobati 5 jenis penyakit, kemudian Annona squamosa (srikaya/garoso mbudi), Psidium guajava (jambu batu/jambu doro),
Morinda citrifolia (mengkudu/nonu) untuk mengobati 4 jenis penyakit (Gambar 2).

Masyarakat Desa Ndano memiliki jenis -jenis ramuan obat tradisional khas suku Mbojo yaitu $l o$ ' $i$ pa'i piri, lo’i pakombo, sampuru, memakai mina cuca dan lo'i bore. Jenis ramuan ini dikelompokan berdasarkan jenis penyakit, komposisi tumbuhan yang digunakan dan cara ramuan obat tersebut diberikan ke pasien (Tabel 3).

Tabel 3. Jenis-jenis ramuan obat tradisional masyarakat suku Mbojo desa Ndano

\begin{tabular}{|c|c|c|c|}
\hline No. & Nama ramuan & Jenis Tumbuhan & Kelompok penyakit/penggunaannya \\
\hline 1. & Lo’i pa’i piri & $\begin{array}{ll}\text { - } & \text { Weru } \\
\text { - } & \text { Jahe } \\
\text { - } & \text { Kunyit } \\
\text { - } & \text { Temulawak } \\
\text { - } & \text { Bawang putih } \\
\text { - } & \text { Kencur } \\
\text { - } & \text { Daun jambu } \\
\text { - } & \text { Kulit manggis } \\
\text { - } & \text { Kulit delima } \\
\text { - } & \text { Daun manira } \\
\text { - } & \text { Sirih } \\
\text { - } & \text { Cengkeh } \\
\text { - } & \text { Cabai hutan } \\
\text { - } & \text { Kadara } \\
\text { - } & \text { Kulit konca } \\
\text { - } & \text { Bunga kepanca } \\
\text { - } & \text { Pala } \\
\text { - } & \text { Musi }\end{array}$ & $\begin{array}{l}\text { Melancarkan peredaran darah, menurunkan } \\
\text { kolesterol, mencegah gula darah, penambah nafsu } \\
\text { makan. }\end{array}$ \\
\hline
\end{tabular}




\begin{tabular}{|c|c|c|c|}
\hline 2. & Lo’i pakombo & $\begin{array}{ll}\text { - } & \text { Temu giring } \\
\text { - } & \text { Cabai hutan } \\
\text { - } & \text { Asam } \\
\text { - } & \text { Kelapa } \\
\text { - } & \text { Gula merah }\end{array}$ & $\begin{array}{l}\text { Penambah nafsu makan, kesuburan wanita, awet } \\
\text { muda, menghilangkan bau badan dan bau mulut. }\end{array}$ \\
\hline 3. & Sampuru & $\begin{array}{ll}\text { - } & \text { Daun sirih } \\
\text { - } & \text { Cengkeh } \\
\text { - } & \text { Kapur } \\
\text { - } & \text { Merica } \\
\text { - } & \text { Jahe } \\
\text { - } & \text { Pinang } \\
\text { - } & \text { Pala } \\
\end{array}$ & $\begin{array}{l}\text { Menghangatkan/menyegarkan badan seperti badan } \\
\text { yang sakit, pegal-pegal, kedinginan, untuk ibu-ibu } \\
\text { hamil, selesai melahirkan dan menyusui, anak-anak } \\
\text { yang sering ngompol. }\end{array}$ \\
\hline 4. & Mina сиса & $\begin{array}{ll}\text { - } & \text { Akar pisang } \\
\text { - } & \text { Akar kedondong } \\
\text { - } & \text { Madu } \\
\end{array}$ & Sakit mata, katarak. \\
\hline & Lo'i bore & $\begin{array}{ll}\text { - } & \text { Cengkeh } \\
\text { - } & \text { Pala } \\
\text { - } & \text { Merica } \\
\text { - } & \text { Bawang putih } \\
\text { - } & \text { Jahe } \\
\text { - } & \text { Kulit kelor } \\
\text { - } & \text { Kunyit } \\
\text { - } & \text { Bangu lae } \\
\text { - } & \text { Musi } \\
\text { - } & \text { Beras } \\
\end{array}$ & $\begin{array}{l}\text { Menghangatkan badan, mengobati semua penyakit } \\
\text { seperti pegal-pegal, melindungi wajah dari sinar } \\
\text { matahari. }\end{array}$ \\
\hline
\end{tabular}

Lo'i pa'i piri atau obat pahit (Tabel 3), dinamakan demikian karena ramuan obat ini berasal dari bahan yang pahit dan sepat, dipercaya memiliki khasiat berbagai macam penyakit. Diantaranya yaitu melancarkan peredaran darah, menurunkan kolesterol, mencegah gula darah dan penambah nafsu makan. Ramuan ini juga biasa dikonsumsi rutin oleh ibu-ibu setelah melahirkan untuk memperbaiki kondisi tubuh, mencegah infeksi dan menguatkan stamina. Ramuan obat ini diracik dengan mengupas bahan-bahannya terlebih dahulu, setelah itu ditumbuk dan diparut. Selanjutnya, disaring dan direbus, air hasil saringan tadi dimasak sampai mendidih, cara penggunaannya dengan cara diminum.

Lo'i pakombo merupakan ramuan obat yang sering digunakan masyarakat Suku Bima-Dompu khususnya masyarakat Desa Ndano. Ramuan obat ini berkhasiat sebagai penambah nafsu makan, kesuburan wanita, awet muda, menghilangkan bau badan dan bau mulut. Ramuan obat ini diolah dengan cara terlebih dahulu dengan mengupas semua jenis bahan yang digunakan, setelah itu ditumbuk atau diparut. Selanjutnya, mengambil ekstraknya dengan cara disaring, ada juga ramuan yang direbus dengan air kemudian disaring, hasil saringan kemudian dikonsumsi dengan cara diminum.

Sampuru merupakan tradisi yang sering dilakukan masyarakat Suku Bima-Dompu dari zaman dulu hingga sekarang dalam memanfaatkan tumbuhan obat, meski hanya sebagian orang saja yang melakukannya. Sebelum dilakukan Sampuru, terlebih dahulu ramuan obat tersebut di Mama atau di kunyah baru kemudian di sampuru. Sampuru artinya mengunyah rempah-rempah lalu disemburkan kepada orang yang sakit atau ke bagian tubuh yang diyakini dapat menyembuhkan penyakit. Sampuru berkhasiat menghangatkan/menyegarkan badan seperti badan yang sakit, pegal-pegal, kedinginan, untuk ibu-ibu hamil, selesai melahirkan dan menyusui, anak-anak yang sering mengompol.

Lo' $i$ bore merupakan ramuan obat yang dioleskan ke seluruh badan. Lo'i bore berkhasiat untuk menghangatkan badan, mengobati semua penyakit seperti pegal-pegal, melindungi wajah dari sinar matahari. Bahan-bahan Lo'i bore dikupas setelah itu ditumbuk dengan air sampai halus, kemudian dibuat bola-bola kecil/besar dan dijemur 
hingga kering. Lo'i bore merupakan ramuan tradisional masyarakat Suku Mbojo pada zaman dulu yang termasuk warisan budaya. Ramuan ini juga diyakini sebagai rahasia kecantikan para wanita Suku Bima-Dompu, karena membantu mengencangkan kulit.

Mina cuca merupakan ramuan obat khas Desa Ndano, ramuan ini hanya diramu oleh Bapak Arifin (Dae Refo). Ramuan ini berkhasiat untuk pengobatan mata seperti katarak, mata minus, dan mata putih yang terkena guna-guna. Ramuan ini terdiri dari tumbuhan akar pisang, akar kedondong yang diambil sarinya dan ditambahkan madu asli.

Masyarakat Desa Ndano memiliki pengetahuan dan cara sendiri dalam memanfaatkan keanekaragaman tumbuhan sebagai bahan obatobatan. Hal tersebut dikaitkan dengan pengetahuan dan kepercayaan masing-masing individu dalam menggunakan tumbuhan sebagai obat. Masyarakat mencari sendiri tumbuhan obat tersebut di dalam kawasan hutan, pekarangan rumah atau kebun serta membelinya di pasar tradisional. Tidak ada syarat atau ritual khusus yang dilakukan pada saat pengambilan tapi hanya ritual membaca do'a agar tumbuhan yang diambil bermanfaat.

Tumbuhan obat merupakan sumberdaya hayati yang dapat digunakan untuk meningkatkan kesejahteraan masyarakat terutama masyarakat di Desa sehingga kegiatan konservasi terhadapnya tidak hanya melakukan perlindungan dan pengawetan tetapi juga diharapkan dapat dilakukan pemanfaatan secara lestari. Pemanfaatan plasma nutfah tumbuhan untuk berbagai keperluan manusia perlu diimbangi dengan upaya konservasi, baik secara insitu maupun eksitu agar tidak terjadi penurunan populasi dan keanekaragamannya (Zuhud et al, 1994).

\section{Kesimpulan}

Berdasarkan hasil penelitian yang dilakukan dapat disimpulkan bahwa tingkat pendidikan mempengaruhi tingkat pendapatan dan kepercayaan masyarakat dalam pemanfaatan tumbuhan obat. Diperoleh 26 spesies tumbuhan obat yang paling dikenal dan sering dimanfaatkan oleh masyarakat Mbojo Desa Ndano. Pemanfaatan tumbuhan obat ini digunakan untuk penyembuhan penyakit yang berjumlah 31 jenis penyakit. Berdasarkan kelompok habitus, tingkat pohon paling banyak dimanfaatkan sebagai obat. Sedangkan, bagian (organ) tumbuhan yang paling banyak dimanfaatkan yaitu daun. Masyarakat Desa Ndano masih menggunakan cara sederhana dalam meramu tumbuhan obat yaitu dengan cara dihaluskan (ditumbuk, diparut, diremas) dan direbus. Sedangkan, penggunaannya dengan cara diminum, dioleskan dan diteteskan. Proses pembuatan obat tradisional oleh dukun/Sandro terkadang membutuhkan beberapa do'a agar tumbuhan yang dibuat berkhasiat untuk menyembuhkan. Hasil penelitian ini sangat berguna bagi pengembangan riset tumbuhan obat berbasis kearifan lokal untuk pengelolaan TWA Madapangga yang berkelanjutan.

\section{Ucapan terima kasih}

Penulis mengucapkan terima kasih kepada semua pihak khususnya pengelola TWA Madapangga dan para narasumber masyarakat Desa Ndano yang telah bersedia berkontribusi dalam meluangkan waktu, tenaga, dan memberikan informasi yang diperlukan dalam penelitian ini.

\section{Referensi}

Ani, N., Rohyani, I. S., \& Ustadz, M. (2018). Pengetahuan Masyarakat Tentang Jenis Tumbuhan Obat Di Kawasan Taman Wisata Alam Madapangga Sumbawa. Jurnal Pijar Mipa, 13(2), 160-166.

Arizona, D. (2011) Etnobotani dan Potensi Tumbuhan Berguna di Taman Nasional Gunungg CiremaiJawa Barat. Skripsi. Fakultas Kehutanan, Institut Pertanian Bogor.

Balai Konservasi Sumber Daya Alam NTB (2017). Statistik Direktorat Jenderal Konservasi Sumber Daya Alam dan Ekosistem Tahun 2017.

http://ksdae.menlhk.go.id/assets/publikasi/Bu ku Statistik DJ KSDAE 2017.pdf

Gunawan, A. (2007). Food Combining, Kombinasi Makanan Serasi Pola Makanan untuk Langsing dan Sehat. PT Gramedia Pustaka Umum. Jakarta. 
Hariana, A. (2005). Tumbuhan Obat dan Khasiatnya. Penebar Swadaya. Jakarta.

Herbie, T. (2015) Kitab Tanaman Berkhasiat Obat. Octopus Publishing House. Yogyakarta.

Hoffman, B., \& T. Gallaher. (2006). Importance Indices in Ethnobotany. A Journal of Plants and Applied Research.

Ismail. (2015). Faktor Yang Mempengaruhi Keputusan Masyarakat Memilih Obat Tradisional Di Gampong Lam Ujong. Idea Nursing Journal.

Kandowangko, N., S, Margaretha, \& A, Jusna. (2011), Kajian Etnobotani Tanaman Obat Oleh Masyarakat Kabupaten Bonebolango Provinsi Gorontalo, Laporan Penelitian Pengembangan Program Studi Jurusan Biologi Fakultas MIPA Universitas Negeri Gorontalo.

Kuntorini, E.M. (2005). Botani Ekonomi Suku Zingiberaceae sebagai Obat Tradisional Oleh Masyarakat di Kotamadya Banjarbaru, Bioscientiae, Vol. 2, No. 1, pp. 25-36.

Metananda, A.A. (2012). Etnobotani Pangan dan Obat Masyarakat Sekitar Taman Nasional Gunung (Studi Kasus Pada Suku Sasak di Desa Jeruk Manis, Kecamatan Sikur, Kabupaten Lombok Timur, Nusa Tenggara Barat). Skripsi. Jurusan Konservasi Sumberdaya, Fakultas Kehutanan, Institut Pertanian Bogor.

Nurrani, L., S. Tabba, \& H.S. Mokodompit. (2015). Kearifan Lokal dalam Pemanfaatan Tumbuhan Obat oleh Masyarakat di Sekitar Taman Nasional Aketajawe Lolobata, Provinsi Maluku Utara, Jurnal Pendidikan Sosial dan Ekonomi Kehutanan, Vol. 12, pp. 164.

Pramesthi, A.Y. 2008). Kajian Etnofitomedika dan Potensi Tumbuhan Obat di Taman Nasional Gunung Rinjani (Studi Kasus di Desa Montong Betok, Kecamatan Montong Gading, Kabupaten Lombok Timur, Nusa
Tenggara Barat), Skripsi, Jurusan Konservasi Sumberdaya Hutan dan Ekowisata, Fakultas Kehutanan, Institut Pertanian Bogor.

Purba, E.R., \& M. Martosipono. (2009). Kurkumin Sebagai Senyawa Antioksidan, Prosiding Seminar Nasional Sains dan Pendidikan Sains IV, No. 3-607-621, Fakultas Sains dan Matematika UKSW Salatiga, 13 Juni 2009.

Rahayu., Mulyati., S, Sunarti., D, Sulistiarini., Suhardjono, \& Prawiroatmodjo. (2014). Pemanfaatan Tumbuhan Obat Secara Tradisional Oleh Masyarakat Lokal Di Pulau Wawoni, Sulawesi Tenggara. Jurnal Biodiversitas. 7 (2), 2-3.

Supardi S, \& Susyanty AL. (2010). Penggunaan Obat Tradisional Dalam Upaya Pengobatan Sendiri Di Indonesia (Analisa Data Susesnas Tahun 2007). Buletin Penelitian Kesehatan. Vol 38. No 2. Pp 80-89.

Zaman, M.Q. (2009). Etnobotani Tumbuhan Obat di Kabupaten Pamekasan Madura Provinsi Jawa Timur. Skripsi. Jurusan Biologi Fakultas Sains dan Teknologi, UIN Maulana Malik Ibramin Malang.

Zuhud, E.A.M, Ekarelawan, \& S. Riswan. (1994). Hutan Tropika Indonesia sebagai Sumber Keanekaragaman Plasma Nutfah Tumbuhan Obat, Dalam Pelestarian Pemanfaatan Keanekaragaman Tumbuhan Obat Hutan Tropika Indonesia, Jurusan Konservasi Sumberdaya Hutan, Fakultas Kehutanan IPBLembaga Alam Tropika Indonesia (LATIN), Bogor. 